\title{
Report proposes US forum to link research to needs
}

\begin{abstract}
Washington. Long-range planning is all the rage among US science policy-makers, and the prize for the most ambitious proposal goes to the Carnegie Commission on Science, Technology and Government, which has this week proposed a national forum to seek a consensus on the country's goals for science and technology. The forum would be based at the US National Academy of Sciences (NAS) and keep its eye on the "big picture' - what the government should expect from its investment in science.

The idea is outlined in the commission's latest report*, released on Wednesday (30 September). It is in tune with the wishes of US Representative George Brown (Democrat, California) and his House science committee, which sponsored a press conference to announce the report, and comes as the directors of the National Institutes of Health and the National Science Foundation are each preparing reports on their agency's future (see Nature 359, $261 \&$ 358, 355; 1992).
\end{abstract}

The field may already seem crowded with such bodies. To mention just a few, there is the Office of Science and Technology Policy and the President's Council of Advisors on Science and Technology, working on behalf of the executive branch; the Office of Technology Assessment (OTA), serving Congress and each of its myriad committees that oversee slices of the research pie; and the NAS itself, offering impartial advice to whichever government body requests it. But this group would be different, insists the chairman of the Carnegie panel, H. Guyford Stever. "The objective is to bring together professionals in science and engineering with people outside the field that nevertheless have a deep interest in how science affects society", he says. "I'm not sure that such a thing is occurring anywhere else."

Carnegie officials have been airing the idea for more than a year and arc pleased to hear some of their ideas in the current debate about the best way to shift the rationale for supporting science from fighting the Cold War to serving the civilian economy and the needs of society. The academy is believed to be drawing up plans for such a national forum, which Stever estimates would cost $\$ 1$ million a year to do properly, and a strong leader is considered vital to its success. Fortunately, there is no shortage of eligible candidates, among them Frank Press, who retires next July as NAS president, and John Gibbons, a member of the Carnegie task force that produced the report, who is thought to favour early retirement from his position as director of OTA.

Jeffrey Mervis

* Enabling the Future: Linking Science and Technology to Societal Goals (Carnegie Commission on Science, Technology and Government, 10 Waverly Place, New York, NY 10003; telephone (212) 998-2150.)

\section{Agencies told to transfer technology — or else}

Washington. A group of industry leaders last week called for a package of new incentives and pressures to force the US national laboratories to do a better job of transferring their technology to industry. In a new report*, the privately financed Council on Competitiveness calls on the government to earmark at least 10 per cent - about $\$ 1$ billion - of the laboratory budgets of the Department of Energy (DOE) and National Aeronautics and Space Administration to technology transfer programmes and to take away that money if certain milestones are not reached.

The report is only the latest proposal to focus the national laboratories on helping US industry instead of on winning the Cold War. But it is the first to suggest potential cuts and still be endorsed by the agencies themselves.

Unlike some previous reports (see $\mathrm{Na}$ ture 356, $372 \& 353,578 ; 1992$ ) the new study does not call for a separate technology transfer centre or company. In particular, the panel rejected the idea of turning one of the DOE laboratories into a technology outlet for the others, on the grounds that having such a clearinghouse would further remove researchers from the marketplace.

In other recommendations, the panel said that laboratory directors should be allowed to negotiate with industry without going through DOE headquarters and direct inhouse research towards specific needs. It also urged the government to set goals that, if not reached in 3-5 years, would result in the money being redirected to more profitable research ventures elsewhere.

However, the panel stopped short of recommending that the laboratories be forced to make up a portion of their budgets with matching funds from industry. That proposal, first aired by the White House Council on Competitiveness, was rejected by everyone from laboratory directors to the companies themselves.

\section{Christopher Anderson}

* Industry as a Customer of the Federal Laboratories (Council on Competitiveness; 1992)

\section{Don't ask for too much, industry tells Congress}

Washington. US high-technology companies do not want the federal government to demand useful products from the research that it funds, seven corporate executives told the US Congress last week. Instead, the government should continue on its present course of training a scientifically literate population and increasing the sum of knowledge in the world.

The occasion was a hearing before the science subcommittee of the House Committee on Science, Space and Technology, whose chairman, US Representative George Brown (Democrat, California), has talked recently about ending "the free ride for science" in the federal budget (see Nature 359,$175 ; 1992$ ). If scientists cannot help to strengthen the US economy, according to one popular refrain, then perhaps they do not deserve to be funded. But what the subcommittee heard from the likes of Arden Bement of TRW Inc., Robert Frosch of General Motors and Theodore Cooper of the Upjohn Company was that the government, in the words of Edward Penhoet of Chiron Corporation, "should do what industry cannot do - education and basic research".

That view is, to be sure, self-serving Industry enjoys being free to pick and choose from among the best that government-funded scientists can offer, turning basic research into products as the opportunity arises, and would rather not be burdened with a meddiesome Congress or federal agency constantly telling it how to invest its resources. But leaving to industry the task of generating wealth also has its benefits: mistakes are the responsibility of the company, not the government, and success is supposed to come to those who know what the public wants and can deliver it.

What the corporate executives want most from the government is the proverbial 'level playing field' with their foreign competitors and an end to troublesome regulations that, as Cooper described them, have the Nuclear Regulatory Commission telling companies to lock the doors of laboratories using radioisotopes at the same time as the Occupational Safety and Health Administration prohibits locks on the doors. They also want to have a voice in shaping forthcoming government decisions affecting research, with Bement complaining about a lack of industrial input in half-a-dozen recent initiatives in such areas as high-performance computing, advanced manufacturing and biotechnology. What they fear is a government determined to create a central plan for research that goes into great detail about the expected return in any number of critical fields.

Jeffrey Mervis 